\title{
MARCIN LASOŃ
}

DOI : 10.14746/rie.2015.9.11

Krakowska Akademia im. Andrzeja Frycza Modrzewskiego

\section{Zaangażowanie Polski w misje wojskowe Unii Europejskiej w Afryce w drugiej dekadzie XXI wieku}

\begin{abstract}
Wstęp
W poprzednim numerze „Rocznika Integracji Europejskiej” ukazał się interesujący tekst Andrzeja Ciupińskiego poświęcony zdolnościom wojskowym Unii Europejskiej (UE), w szczególności perspektywą grup bojowych (Ciupiński, 2014, s. 105-120). Autor w ostatniej części tekstu odnosi się do polskiego zaangażowania w tym obszarze i dokonuje analizy działań, jak i deklaracji polskich władz. Stawia tezę, że w sytuacji kryzysowej bardziej prawdopodobne jest użycie Sił Odpowiedzi NATO niż Grup Bojowych Unii Europejskiej oraz stwierdza, że rząd polski po swoim wcześniejszym silnym zaangażowaniu w rozwój unijnych zdolności wojskowych zmienił politykę i postanowił je ograniczyć. Do powodów takiego stanu rzeczy należy niechęć do użycia grup bojowych panująca w wielu krajach UE i wynikające $\mathrm{z}$ tego przeświadczenie, że na faktyczne wsparcie wojskowe Polska może liczyć tylko w ramach NATO. Trudno nie zgodzić się z tymi tezami. Warto jednak je sprawdzić biorąc pod uwagę nie tylko zaangażowanie w grupy bojowe, ale i na przykładzie udziału w misjach wojskowych w Afryce w drugiej dekadzie XXI wieku. Będzie to tym bardziej interesujące, że można to będzie porównać do uczestnictwa w misjach realizowanych tam wcześniej.

W ten sposób głównym celem analizy będzie przedstawienie stanu zaangażowania Polski w misje UE w Afryce w kontekście prowadzonej przez nią polityki bezpieczeństwa i uczestnictwa w rozwoju Wspólnej Polityki Bezpieczeństwa i Obrony UE. Dlatego główny problem badawczy zamyka się w pytaniu: jakie jest zaangażowanie Polski w misje wojskowe UE w drugiej dekadzie XXI wieku? Problemy szczegółowe zaś to:

- jak zmieniło się polskie zaangażowanie w afrykańskie misje unijne na przestrzeni ponad 10 lat członkostwa w Unii?

- z czego wynikają wprowadzone zmiany?

- jaka jest przyszłość polskiego zaangażowania w tego typu operacje?

By na nie odpowiedzieć, Autor skorzysta z dostępnych źródeł i literatury przedmiotu, dokonując jej analizy i wyciągając wnioski. Tego typu tematyka podejmowana jest zarówno przez naukowców cywilnych, jak i wojskowych, jednak w zależności od profilu badacza koncentrują się oni na kwestiach politycznych (w tym w szczególności integracyjnych, jak wspomniany już tekst Ciupińskiego czy praca pod redakcją Beaty Przybylskiej-Maszner (Poznań, 2014)), jak i wojskowych, z perspektywy technicznego opisu narzędzia, jakim posługują się władze prowadząc politykę zagraniczną i bezpieczeństwa państwa, np. Leszek Elak (Warszawa, 2010) czy szereg prac pod redakcją Dariusza Kozerawskiego.
\end{abstract}




\section{Stan obecny}

Aktualne dane dotyczące zaangażowania Wojska Polskiego w działania poza granicami kraju znaleźć można w stenogramie sprawozdania posiedzenia senackiej Komisji Obrony Narodowej z 5 lutego 2015 roku (Zapis stenograficzny, 5 II 2015). Zawiera on informację Ministra Obrony Narodowej (MON) za okres 2014 roku. Warto podkreślić, że już na wstępie referujący ją Podsekretarz Stanu w MON Maciej Jankowski podaje, że Polska bierze aktywny udział w misjach NATO, UE oraz Organizacji Narodów Zjednoczonych. W wypadku Unii wskazuje, że Polska bierze lub brała aktywny udział w szczególności w misji w Bośni i Hercegowinie, ale i w Republice Środkowoafrykańskiej (w tym we wcześniejszej fazie zaangażowania sił międzynarodowych poprzez wsparcie sił francuskich w zakresie wsparcia logistycznego) oraz w zakończonej w 2014 roku misji w Mali. Warto dodać, że podano także iż Polska obsadziła 20 stanowisk w strukturach unijnych, przede wszystkim w sztabie wojskowym. Jest to zdecydowanie mniejsza skala niż w wypadku NATO, co w tym wypadku nie może budzić zdziwienia, biorąc pod uwagę charakter i specyfikę obu organizacji. Zdecydowanie ciekawsze jest to, że w 2014 roku polscy żołnierze wzięli udzial tylko w jednych ćwiczeniach wojskowych pod auspicjami UE, ale już 10 natowskich. To fakt, który prowadzi do wniosków dotyczących nie tylko stanu wojskowej współpracy państw Unii, ale i znaczenia, jakie dla Polski ma bezpieczeństwo militarne i związane z nimi znaczenie obu organizacji.

Jeżeli zaś chodzi o zaangażowanie polskie w kontyngenty wojskowe (PKW) w Afryce, to podchodząc do rzeczy systematycznie i syntetycznie podać należy, że (Zapis stenograficzny, 5 II 2015):

- PKW w Republice Środkowoafrykańskiej, działał od 1 lutego do 25 kwietnia 2014 roku. Nie był kontyngentem skierowanym na misję UE, ale wspierał działania wojsk francuskich w tym państwie poprzez usługi transportowe. Kontyngent liczył 34 żołnierzy stacjonujących we Francji, z której wykonywano loty do Republiki Środkowoafrykańskiej samolotem C-130 Hercules. Zrealizowano ich siedem. Koszty jego funkcjonowania oszacowano na ok. $2 \mathrm{~m} \ln$ pln. Trzeba podkreślić, że misja była realizowana $w$ ramach współpracy dwustronnej z Francją, miała zatem inny charakter, celowała w pomoc ważnemu dla Polski sojusznikowi europejskiemu, którego ranga jest podnoszona przez władze państwowe;

- w kwietniu 2014 roku rozpoczęła się misja wojskowa UE w Republice Środkowoafrykańskiej (EUFOR RCA). PKW skierowany tam został zgodnie z postanowieniem Prezydenta RP z 12 grudnia 2014 roku z mandatem do 15 marca 2015 roku i określeniem liczebności na 50 żołnierzy (Monitor Polski, 15 XII 2014). Głównym jego trzonem został pluton żandarmerii wojskowej realizujący zadania patrolowe i prewencyjne, a celem misji jest zapewnienie warunków do udzielania pomocy humanitarnej. Wydatki na PKW oszacowano na ok. $6 \mathrm{mln}$ pln, a koniec obecności nastąpił w lutym 2015 roku. Zdecydowano jednak o dalszym zaangażowaniu w tym państwie poprzez włączenie w nową misję UE (EUMAM RCA). Prezydent wydał odpowiednie postanowienie 14 kwietnia 2015 roku (Monitor Polski, 14 IV 2014). Zgodnie z nim polski wkład w misję szkoleniową miał liczyć do 2 żołnierzy. Co prawda była to już misja określana jako doradcza/szkoleniowa, a nie operacja woj- 
skowa, ale niezależnie od tego wkład w nią można uznać jako symboliczny, chociaż taki charakter ma także sama misja, o czym dalej;

- PKW w Mali, którego pierwsza zmiana działała w tym państwie od marca 2013 roku, a druga w okresie od września 2013 roku do maja 2014 roku. PKW był elementem misji szkoleniowej UE (EUTM Mali) i liczył 20 osób. Jego celem było szkolenie i doradztwo siłom zbrojnym Mali, w szczególności kompaniom logistycznym armii malijskiej, jak i zabezpieczenie logistyczne bazy szkoleniowej oraz realizacja zadań transportowych dla dowództwa misji (Pelny zapis przebiegu, 8 X 2014). Koszt polskiego zaangażowania wyniósł ok. $3,2 \mathrm{~m} \ln$ pln. Odpowiednie postanowienie w sprawie utworzenia PKW na rzecz udziału w misji szkoleniowej UE w Mali wydał Prezydent RP 7 lutego 2013 roku (Monitor Polski, 13 II 2013);

- dla uzupełnienia dodać należy, że PKW działa nadal w ramach misji UE w Bośni i Hercegowinie, ale w 2014 roku liczył już tylko 39 osób. Miał więc już charakter symboliczny.

Jednak wydatki na jego utrzymanie wyniosły w 2014 roku ok. $6 \mathrm{mln}$ pln, zatem więcej niż na wcześniej wspomniane misje afrykańskie. Wykonywał zadania szkoleniowe oraz monitorowania sytuacji bezpieczeństwa w wyznaczonym rejonie.

Autor nie będzie szerzej omawiał działań wspomnianych kontyngentów w Afryce. Ograniczy się tylko do podanych wiadomości, zachęcając zainteresowanych czytelników do zapoznania się z informacjami na ten temat publikowanymi przez źródła wojskowe ( $P K W$ Mali, 2015). Natomiast z perspektywy dokonywanej analizy istotne jest jak to zaangażowanie przedstawiało się na tle innych państw wysyłających żołnierzy na wspomniane operacje unijne. Będzie to więc porównanie ilościowe.

Zgodnie z dostępnymi danymi w czerwcu 2014 roku misję unijną w Republice Środkowoafrykańskiej rozpoczęło 700 żołnierzy z 10 krajów, później dołączyły do niej Włochy z 50 żołnierzami (EUFOR RCA, 13 VII 2015). W ten sposób polskie zaangażowanie w liczbie 50 żołnierzy stanowiło $1 / 15$ całych sił w rejonie działań. W wypadku misji szkoleniowej 2 polskich żołnierzy jest częścią kontyngentu europejskiego liczącego 60 żołnierzy, zatem stanowi $1 / 30$ sił. W tym sensie zatem zarówno wkład polski, jak i unijny, jest symboliczny.

W wypadku misji w Mali, z której Polska wycofała się przed jej zakończeniem, wielkość zaangażowanych sił szacowano na ok. 550 żołnierzy, które wysłało nieco ponad 20 państw. Większy od Polski wkład zadeklarowali np. Czesi, bo ok. 30 żołnierzy (EUTM Mali, 13 VII 2015). Zatem pokazując rzecz liczbowo, siły polskie stanowiły ok. 1/27 całości misji unijnej.

Podsumowując należy stwierdzić, że w wypadku obu afrykańskich misji unijnych, na uczestnictwo w których zdecydowano się wysłać żołnierzy Wojska Polskiego, wkład Polski miał charakter symboliczny pod względem ilościowym. Co więcej, wraz ze zmianą charakteru misji zmniejszył się jeszcze bardziej (Republika Środkowoafrykańska), lub PKW został wycofany (Mali). W tym miejscu trzeba przypomnieć, że inaczej rzecz miała się z kontyngentami wysyłanymi na misje afrykańskie UE jeszcze w pierwszej dekadzie XXI wieku. Mowa tutaj o Demokratycznej Republice Konga (EUFOR RD CONGO) oraz w Czadzie i Republice Środkowoafrykańskiej (EUFOR TCHAD/RCA). W wypadku tej pierwszej Polska wystawiła 3 lub 4 (zależnie od sposobu liczenia) pod względem wielkości kontyngent liczący 130 żołnierzy, dedykowany 
do trudnych zadań, stanowiących ok. 1/10 sił rozmieszczonych bezpośrednio na terenie Demokratycznej Republiki Konga. W wypadku misji w Czadzie polski kontyngent był na równi z irlandzkim drugi pod względem wielkości i liczył ok. 400 żołnierzy. Biorąc pod uwage całość sil stanowił ponad $1 / 8$ całości. W tym strona polska wysłała śmigłowce, bez których rozpoczęcie działań przez EUFOR byłoby w zasadzie niemożliwe (Lasoń, 2010, s. 229-245; Rawski, 2011, s. 30-83). Biorąc pod uwagę zaprezentowane dane można stwierdzić jednoznacznie, że skala polskiego zaangażowania w operacje wojskowe UE na terenie Afryki (i nie tylko) znacząco zmalała, co obrazowo pokazuje poniższa tabela. Pora spróbować odpowiedzieć na pytanie dlaczego tak się stało?

Tabela 1

Porównanie wielkości PKW na misjach UE w Afryce

\begin{tabular}{||l|c|c|c|c||}
\hline \multicolumn{1}{|c|}{ Rok/Państwo } & $\begin{array}{c}\text { Demokratyczna } \\
\text { Republika Konga }\end{array}$ & $\begin{array}{c}\text { Republika } \\
\text { Czadu/Republika } \\
\text { Środkowoafrykańska }\end{array}$ & Republika Mali & $\begin{array}{c}\text { Republika Środko- } \\
\text { woafrykańska }\end{array}$ \\
\hline 2006 & 130 osób & 400 osób & & \\
\hline 2009 & & & 20 osób & 34 osoby \\
\hline $2013-2014$ & & & & 50 osób \\
\hline 2014 & & & & 2 osoby \\
\hline $2014 / 2015$ & & & & \\
\hline 2015 & & & & \\
\hline
\end{tabular}

Źródło: Opracowanie własne.

\section{Powody}

W najprostszych słowach można odpowiedzieć słowami Prezydenta RP Bronisława Komorowskiego, który podczas obchodów Święta Wojska Polskiego w sierpniu 2013 roku stwierdzil, że: „Zdecydowanie odchodzimy od nadgorliwie, nieopatrznie ogłoszonej w 2007 roku polityki ekspedycyjnej. Koniec łatwej polityki, łatwego wysyłania żołnierzy polskich na antypody świata [...] chcemy jak największe środki budżetowe przynależne Siłom Zbrojnym przeznaczać nie na misje zewnętrzne, ale na modernizację armii polskiej pod kątem potrzeb obronnych naszego terytorium, pod kątem potrzeb systemu obronnego sił NATO, także na rzecz naszych partnerów w Sojuszu" (Prezydent: Koniec, 2013). W tym cytacie tkwi sedno tzw. Doktryny Komorowskiego opublikowanej przez Biuro Bezpieczeństwa Narodowego 17 lutego 2014 roku (Doktryna, 2014). Stała się ona nieformalną podstawą prowadzonej przez Prezydenta polityki związanej z Siłami Zbrojnymi RP i realizowanej także przez polski rząd, a której elementy zawarto w wydanej w 2013 roku Białej Księdze Bezpieczeństwa Narodowego RP (Biała Księga, 2013). Mówi ona, że priorytetem Sił Zbrojnych RP ma być obrona terytorium państwa, a nie udział w misjach ekspedycyjnych. Te bowiem, wg autorów, ograniczały możliwości obronne Sił Zbrojnych RP, w szczególności bezpośredniej obrony terytorium państwowego. Podkreślono, że nie oznacza to całkowitej rezygnacji z misji, a jedynie ich ograniczenie do „właściwego miejsca w hierarchii zadań dla pań- 
stwa i sił zbrojnych" (Doktryna, 2014). Tym bardziej, że podkreślono także znaczenie gotowości do obrony sojuszników, co jest jednym z priorytetów Polski. Stąd dalej podano, że polską specjalnością w NATO mają być zdolności obronne. Gdyby interpretować to dosłownie, to można byłoby stwierdzić, że Polska ma się specjalizować w obronie własnej i sojuszników, do czego przecież nie jest konieczna żadna specjalizacja, a jest to podstawowy obowiązek każdego członka wynikający z zapisów Traktatu Waszyngtońskiego. Takie zdolności ma zaś osiągnąć, ograniczając ekspedycyjność armii, zatem jej zdolność do działania poza granicami kraju. To sprzeczność, chociaż można jej uniknąć, jeśli doda się, że takie zdolności mają być osiągane poprzez wspólne ćwiczenia, co jednak nie wydaje się wystarczające w chwili, w której możliwe jest prowadzenie wspólnych operacji wojskowych na prawdziwym a nie symulowanym polu walki. O tym jednak w dokumencie nie ma mowy (porównaj z entuzjastyczną oceną dokumentu: Fryc, 2014, s. 50-51). Warto dodać jako ciekawostkę, że z tekstu wynika zatem także, że taką specjalnością nie mają już być Wojska Specjalne, co deklarowano od 2002 roku i na rzecz czego działano przez wiele lat. To prowadzi do konstatacji, że przyjęta reforma Kierowania i Dowodzenia Siłami zbrojnymi RP, która weszła w życie 1 stycznia 2014 roku i która zniweczyła wiele lat pracy nad stworzeniem sprawnego systemu wojsk specjalnych w Polsce, nie zrobiła tego przypadkowo, a z rozmysłem. W to miejsce weszła obronna specjalność strategiczna.

Wróćmy jednak do Doktryny, która nieco dalej podaje, że mają nią być „zdolności przeciwzaskoczeniowe, konieczne zwłaszcza w sytuacjach trudnokonsensusowych" (Doktryna, 2014). Pomijając to niezbyt fortunne sformułowanie, które jednak autorzy wyjaśniają w sposób przejrzysty (mówiąc o zdolności do obrony własnego terytorium w sytuacji niewypowiedzianej wojny i dłuższego oczekiwania na decyzję sojuszników), wskażmy na zapis dotyczący Unii Europejskiej. Otóż autorzy podają, że: „Co do UE to nasze działania powinny zmierzać do wzmacniania Wspólnej Polityki Bezpieczeństwa i Obrony, aby mogła być drugim, obok NATO, zewnętrznym filarem wzmocnienia bezpieczeństwa Polski" (Doktryna, 2014). Z tego zatem wynika, że z jednej strony Polska powinna ograniczać swój udział w operacjach ekspedycyjnych, z drugiej zaś dążyć do rozwoju Wspólnej Polityki Bezpieczeństwa i Obrony UE (WPBiO UE), której jednym z elementów jest posiadanie zdolności i wykonywanie zadań z obszaru reagowania kryzysowego. Podobnie w wypadku NATO, który zgodnie z Koncepcją Strategiczną z Lizbony, także ma wykonywać tego typu zadania i jest to jego drugie zadanie po kolektywnej obronie państw członkowskich. Biorąc to pod uwagę warto zapytać co kryje się pod cytowanym już stwierdzeniem, że misje powinny zajmować właściwe miejsce w hierarchii zadań dla państwa i sił zbrojnych? Jeżeli z jednej strony zostały radykalnie ograniczone, $\mathrm{z}$ drugiej zaś ich prowadzenie jest niezbędne do właściwego wywiązywania się z obowiązków sojuszniczych, jak i wsparcia projektu WPBiO UE. Niestety nie można znaleźć przekonującej odpowiedzi na tak postawione pytanie. Poza tą, którą podają statystyki, a te wskazują na symboliczny charakter zaangażowania w operacje poza granicami kraju, szczególnie w ramach Unii Europejskiej. Tym samym faktycznie marginalnego traktowania tego filaru polskiej polityki bezpieczeństwa, co zresztą koresponduje z tezą Ciupińskiego (Ciupiński, 2014, s. 117).

Jak jednak ma się to do założeń przyjętych przez polski rząd? Na to pytanie odpowiedź znaleźć można w dokumencie przyjętym przez Radę Ministrów w marcu 2012 roku 
pt. „Priorytety polskiej polityki zagranicznej 2012-2016” (Priorytety, 2012). Jej autorzy podają, że jednym z celów Polski jest: „rozwijanie zdolności UE w sferze samodzielnych oraz komplementarnych wobec NATO środków i zasobów budowania bezpieczeństwa” (Priorytety, 2012, s. 6). A dalej: „Kluczowy dla UE jest również rozwój Wspólnej Polityki Bezpieczeństwa i Obrony (WPBiO) UE oraz Przestrzeni Wolności, Bezpieczeństwa i Sprawiedliwości, który jednak będzie procesem dhugotrwałym. Docelowo WPBiO powinno pozyskać zdolności wojskowe i cywilne, które będą dobrze uzupełniały transatlantycki system bezpieczeństwa" (Priorytety, 2012, s. 12). Widać zatem, że mimo, iż dla Polski jest to rzecz kluczowa, to nie będzie ona zajmowała kluczowego miejsca w jej polityce, czego dowodzą przedstawiane wcześniej przykłady. Warto jednak zauważyć, że autorzy stwierdzają, że rozwój WPBiO UE jest procesem długotrwałym, a zatem $w$ ten sposób podkreślają, że nim osiagnie ona oczekiwany przez Polskę poziom, to upłynie dużo czasu. Jak widać Polska poprzez swoje symboliczne zaangażowanie nie ma teraz zamiaru tego procesu przyspieszać. Prowadzi to jednak do pewnego wniosku, a mianowicie rządzący Polska, mając ograniczone środki polityki zagranicznej i bezpieczeństwa nie są $w$ stanie uczynić wiele na rzecz rozwoju WPBiO UE i zdaja sobie $z$ tego sprawę. $Z$ drugiej jednak strony ich decyzje ograniczające je do poziomu symbolicznego stoją w sprzeczności z głoszonymi oczekiwaniami. Można przypuszczać, że to właśnie niewielkie zasoby (zarówno materiałowe jak i ludzkie w Wojsku Polskim) skłoniły polskich decydentów do podjęcia decyzji o ograniczeniu ekspedycyjności i skupieniu się na zdolnościach obronnych, przede wszystkim własnego terytorium. Tym bardziej, że tego typu sytuacja miała już miejsce w wypadku wycofania polskich kontyngentów z operacji pokojowych ONZ w 2009 roku. Motywowano to w inny sposób, ale faktyczny powód był właśnie taki. Doprowadziło to do obniżenia rangi Polski w ONZ i zerwania z ponad 50-letnim poważnym zaangażowaniem w misje tego typu ograniczając je tylko do pojedynczych ekspertów i obserwatorów ulokowanych w różnych operacjach, łącznie kilkunastu. Oprócz tego wymienić należy kilka innych powodów:

- polityka Federacji Rosyjskiej, w szczególności aneksja Krymu i prowadzenie działań bezpośrednich i pośrednich na wschodzie Ukrainy. Jednak te wydarzenia miały miejsce już po ogłoszeniu i przyjęciu tej koncepcji polityki ograniczenia ekspedycyjności, zatem mogły jedynie potwierdzić jej słuszność i podać dodatkowe argumenty za nią;

- negatywne stanowisko opinii publicznej w sprawie wysyłania polskich żołnierzy poza granice państwa na misje inne niż pokojowe prowadzone przez Organizację Narodów Zjednoczonych, związane przede wszystkim z zabitymi i rannymi Polakami na misjach oraz konsekwencjami, jakie są widoczne po powrocie żołnierzy do kraju;

- potrzeba środków na prowadzenie modernizacji Wojska Polskiego i związane z tym niezwykle kosztowne projekty, takie jak chociażby zakup śmigłowców czy budowa polskiej „tarczy antyrakietowej”. Operacje finansowane ze środków MON ograniczały środki na ten cel, bo nie stworzono innego mechanizmu ich finansowania;

- wyczerpanie misją w Afganistanie, związanymi z nią kosztami, ludzkimi, jak i finansowymi i materiałowymi;

- po doświadczeniach z okresu pierwszych lat członkostwa w Unii powstało przekonanie, że UE nie będzie gwarantem bezpieczeństwa Polski, a WPBiO pozostanie je- 
dynie w sferze deklaracji i polityki gestów oraz symbolicznej realizacji (np. na podstawie faktu nie użycia stworzonych przecież Grup bojowych), wobec tego nie ma potrzeby znacznego angażowania się w jej rozwój (jak to czyniono np. poprzez wkład we wcześniejsze misje afrykańskie), tak długo, jak długo poważnie nie przystapią do tego większe państwa Unii, w szczególności póki nie zrozumieją zagrożeń istniejących za jej wschodnią granicą (Zięba, 2012, s. 160-169). Słuszność tego podejścia potwierdził szczyt Rady Europejskiej w grudniu 2013 roku poświęcony WPBiO, na którym nie zdecydowano o pracach nad nową strategią bezpieczeństwa zewnętrznego UE, na czym Polsce zależało;

- chęć wywierania nacisku na pozostałych członków NATO by działalność Paktu ograniczała się przede wszystkim do kolektywnej obrony, a nie prowadzenia operacji reagowania kryzysowego, przy tym postulat ,wzmocnienia artykułu piątego" był już widoczny wcześniej i próba uzyskania tegoż wzmocnienia podjęta przez Ministra Obrony Narodowej Bogdana Klicha na szczycie w Lizbonie wedle jego samego, zakończyła się sukcesem, uznano to za właściwy kierunek i w ten sposób postanowiono go rozwijać.

Taka argumentacja nie uwzględnia jednak pewnych korzyści, jakie związane były ze znaczniejszym zaangażowaniem w operacje wojskowe poza granicami kraju i nie mowa tutaj o ekspedycyjności, bo wielkość wszystkich razem PKW poza granicami kraju nie przekraczała nigdy tzw. wskaźnika Robertsona, a zatem nie była nawet równa oczekiwaniom stawianym członkom NATO. Zgodnie z nim $8 \%$ sił lądowych państwa NATO powinno być stale w stanie wysokiej gotowości bojowej lub znajdować się na misjach poza granicami kraju, a $40 \%$ posiadać zdolność do udziału w operacjach na odległości strategiczne, w praktyce zdolność do udziału do kolektywnej obrony (Ojrzanowski, 2013, s. 132).

W ten sposób Polska nie powinna dążyć do nowej specjalizacji, ale zacząć od budowania zdolności do wykonywania podstawowych obowiązków sojuszniczych, niezależnie od tego, że inne kraje NATO mogą także nimi nie dysponować. W związku z tym trzeba pamiętać, że rzeczywiste zmiany w polskiej armii po jej przystappieniu do NATO zaczęły się ze względu na udział $w$ operacjach poza granicami kraju. W pierwszej kolejności stało się to ze względu na doświadczenia nabyte w Iraku, które wymusiły modernizację, zarówno wyposażenia indywidualnego żołnierzy, jak i wykorzystywanego przez nich sprzętu, zaczynając od samochodów, poprzez operację natowską w Afganistanie i wdrożenie tzw. pakietu afgańskiego. Niebagatelną rolę odegrało także zdobyte podczas misji, także unijnych, doświadczenie. Zwykle podawano je jako jedną z największych zalet udziału Wojska Polskiego w operacjach poza granicami kraju zapominając, że nie to było ich podstawowym celem. Po 2013 roku z tej korzyści Polska w zasadzie rezygnuje, a jednocześnie wielu żołnierzy, którzy owo doświadczenie nabyli, odchodzi ze służby po 12 latach, co jest wymuszane przez obowiązujące przepisy. Ich następcy zdobywać je zatem będą jedynie na wspólnych éwiczeniach, natowskich (dla przypomnienia dziesięć w 2014 roku) czy unijnych (jedno w 2014 roku). Można zgodzić się z tezą, że podczas misji żołnierze zdobywali inne umiejętności niż te preferowane w działaniach obronnych na terenie Polski, bo Irak czy Afganistan maja zupełnie inną specyfikę, tak samo jak inną miały zadania tam realizowane np. przeciwpartyzanckie. Jednak istota zdobytych umiejętności - użycia broni w warunkach wo- 
jennych, współdziałania w drużynie, plutonie itd. działania centrum dowodzenia, współpracy międzynarodowej, prowadzenia operacji połączonych, pozostaje niepodważalna $\mathrm{i}$ do osiagnięcia w tej formie jedynie podczas realnych działań. I dlatego właśnie uzasadnioną wydaje się teza, że tak dalece ograniczone zaangażowanie w misje, także te Unii Europejskiej, o których mowa w tekście, nie wpłynie na podniesienie poziomu bezpieczeństwa Polski, ani tym bardziej na rozwój WPBiO UE deklarowany przecież w różnych dokumentach (np. Strategia udzialu, 13 I 2009).

Ten sam wniosek nasuwa się wtedy, kiedy przeniesiemy się na poziom relacji sojuszniczych, a nie tylko technicznej współpracy wojskowej i rozwoju wojska jako takiego. Przecież udział w misjach poza granicami kraju jest jasnym przekazem dla sojuszników, że Polska wspiera ich w potrzebie i sama także na takie wsparcie liczy. Zwracają na to uwagę analitycy PISM stwierdzając nawet, że: „,Dlatego stopniowe odchodzenie Polski od udziału w misjach stabilizacyjnych i pokojowych może zaszkodzić polskiej zdolności do budowania koalicji wokół własnych interesów w ramach UE i NATO. W dłuższej perspektywie stanowi to zagrożenie dla bezpieczeństwa nie tylko Polski, ale i całej Europy Środkowo-Wschodniej" (Radziejowska, Terlikowski, 2014). Wskazują ponadto na proponowany przez siebie sposób zaangażowania przez Polskę w tego typu operacje i inne kwestie szczególowe. Jednak podstawowy wniosek jest jeden - Polska powinna kontynuować zaangażowanie w operacje ekspedycyjne. Ważnym motywem jest także to, że stwarza to później szansę na zaangażowanie gospodarcze w danym terenie, oczywiście, jeśli operacja zostanie właściwie przeprowadzona, a politycy wykorzystają stworzoną w ten sposób szansę, co do tej pory właściwie nie miało miejsca, a czego dobrym przykładem jest chociażby niedawna likwidacja nawet polskiej ambasady w Afganistanie.

Krytycznie do skali polskiego zaangażowania w misje Unii w Afryce podchodzi także Joanna Dobrowolska-Polak, która twierdzi, że: „Zaangażowanie Polski w Afryce w misjach UE na przełomie 2013 i 2014 r. jest relatywnie niewielkie i niewspółmierne do wielkości państwa oraz jego aspiracji do pełnienia znaczącej roli w ramach WPBiO UE" (Dobrowolska-Polak, s. 9). Autorka dowodzi, że powodem takiego stanu rzeczy jest marginalne traktowanie przez Polskę Afryki, jako obszaru, w którym państwo nie ma żywotnych interesów. W związku z tym ewentualne zaangażowanie jest związane przede wszystkim ze wsparciem ważnych dla Polski państw np. Francji czy Niemiec oraz sytuacja, w której Unia jako całość zdecydowałaby się na znaczące zaangażowanie na tym obszarze. Biorąc jednak pod uwagę aspiracje związane $z$ rozwojem i znaczeniem WPBiO, a szerzej Unii Europejskiej jako jednego z filarów bezpieczeństwa Polski, to zaangażowanie powinno być większe. Niezależnie od tego, że jak mówi przyjęta w 2014 roku Strategia bezpieczeństwa Narodowego RP: „Unia Europejska wspiera rozwój społeczno-gospodarczy Polski i umacnia jej pozycję na świecie" (Strategia bezpieczeństwa, 2014, s. 9). Akcentuje więc rolę Unii jako organizacji, która zapewnia Polsce bezpieczeństwo ekonomiczne, a nie militarne. Chociaż dalej czytamy, że WPBiO to istotny czynnik bezpieczeństwa Polski i powinna ona ambitnie podchodzić do wyzwań z nią związanych (Strategia bezpieczeństwa, 2014, s. 9). W tym sensie zatem kolejny raz jest to spotkanie $\mathrm{z}$ deklaracjami, które po próbach wprowadzania w życie we wcześniejszym okresie członkostwa, przeszły do poziomu werbalnego i przyjęcia, że realizacja ambitnego projektu WPBiO UE zależy przede wszystkim od 
największych państw Unii. Jest to trzeźwa ocena sytuacji oznaczająca wyciaggnięcie wniosków z dotychczasowych doświadczeń, ale która nie powinna zmieniać w sposób radykalny zaangażowania Polski w ten projekt, w tym w operacje wojskowe, w które zaangażowanie powinno być na wcześniejszym poziomie. By było „współmierne do wielkości państwa oraz jego aspiracji”, jak to ujęła Dobrowolska-Polak. Nie można ograniczać się do zaangażowania w rozwój Grup bojowych UE i czynić z tego miernika realizacji celu operacyjnego, jakim wg autorów Strategii rozwoju systemu bezpieczeństwa narodowego Rzeczypospolitej Polskiej 2022 jest kształtowanie stabilnego międzynarodowego środowiska bezpieczeństwa w wymiarze regionalnym i globalnym, a w ramach niego rozwój zdolności UE do prowadzenia kompleksowych działań w zakresie reagowania kryzysowego (Strategia rozwoju, 2013, s. 37-41). Jednak ze względu na zmianę na stanowisku Prezydenta RP i związane $z$ tym zmiany $w$ Biurze Bezpieczeństwa Narodowego, które było architektem omawianych koncepcji, można spodziewać się, że zgodnie z polską tradycją, nowi kierujący polską polityką bezpieczeństwa mogą mieć inne koncepcje z nią związane. Tym bardziej, gdy dojdzie także do zmiany rządu w efekcie jesiennych wyborów. Wtedy mogą zacząć powstawać nowe strategie, a zaangażowanie w operacje wojskowe poza granicami kraju, w tym w misje Unii Europejskiej, może przybrać inne rozmiary i formy.

\section{Zakończenie}

W przeprowadzonej analizie Autor starał się odpowiedzieć na dwa z postawionych na wstępie pytań, które korespondują z głównym problemem badawczym. Wykazano, że skala polskiego zaangażowania w operacje wojskowe Unii Europejskiej zdecydowanie zmalała w stosunku do operacji, w jakich Polska brała udział w pierwszej dekadzie XXI wieku. Podano także powody takiego stanu rzeczy, odwołując się zarówno do koncepcji, decyzji i ich realizacji, jak i motywów, jakie kierowały decydentami. $\mathrm{Na}$ trzecie z pytań szczegółowych, dotyczące perspektyw można spróbować odpowiedzieć w tym miejscu. Trudno odnosić się do programu politycznego czy deklaracji prezydenta elekta Andrzeja Dudy. Wielką burzę wywołała wypowiedź dotycząca możliwości wysłania polskich wojsk na Ukrainę, która później była wyjaśniania, że takiego zamiaru ani poglądu ówczesny kandydat na prezydenta nie miał. Można jednak odwołać się do programu Prawa i Sprawiedliwości z 2014 roku, w którym w wypadku wojska czytamy, że po przejęciu władzy dojdzie do zwiększenia liczebności armii, a doświadczenia irackie i afgańskie uznano za przełomowe dla zmian w wojsku (Zdrowie, 2014, s. 161-162). Z tego można wnioskować, że przedstawiciele tej opcji politycznej doceniają skutki wysyłania Wojska Polskiego na operacje wojskowe poza granicami państwa. Jednak priorytetem ma być rozwój zdolności obronnych NATO, a obecność wojskowa na świecie ma być ściśle związana z polskim interesem narodowym. To akurat sformułowania podobne do tych z obowiązujących dokumentów. Rzecz jasna na tyle ogólne, że dopiero podjęte działania będą wskazywały na to, jaką drogą chce podążać nowy Prezydent RP i ewentualnie nowy rząd. Wspominając jednak lata 2005-2007 trudno zapomnieć o zdecydowanej woli uczestnictwa w operacji irackiej i chęci jego wydłużenia poza okres nakreślony wtedy przez nowy rząd koalicji PO-PSL, 
ogłoszeniu zdecydowanego zwiększenia zaangażowania militarnego w Afganistanie oraz wysłania znacznego kontyngentu na misje wojskowe Unii Europejskiej w Afryce. Dlatego można przypuszczać, że ewentualna zmiana władzy w Polsce sprawi, że armia będzie częściej wykorzystywana poza granicami kraju i nie tylko w symboliczny sposób (tym bardziej, że ma wzrosnąć jej liczebność, jak i finansowanie). Z zastrzeżeniem pewnego sceptycyzmu, z jakim PiS patrzy na WPBiO obawiając się, że zagraża ona roli NATO jako podstawowego gwaranta bezpieczeństwa i obecności USA w Europie oraz ewentualnego źródła ograniczania suwerenności w obszarze bezpieczeństwa. A przecież rozwój WPBiO UE jest trudny do pogodzenia z tym faktem, oczywiście w granicach akceptowalnych, zgodnie z kryterium interesów narodowych. O tym sceptycyzmie przekonuje też program z konferencji programowej PiS w Katowicach z 2015 roku. W części obrad poświęconej obronie narodowej znalazło się miejsce na zewnętrzne filary bezpieczeństwa wojskowego Polski - współpraca militarna z USA i NATO, współpraca wojskowa w regionie (Myśląc, 2015, s. 6). To dosłowny tytuł panelu dyskusyjnego, który jasno pokazuje priorytety w tym obszarze i ewentualne miejsce zaangażowania w operacje wojskowe Unii Europejskiej. Będzie ono z dala za podanymi w tytule, ale istniejące, jako element szerszej koncepcji polityki bezpieczeństwa i jej elementu w postaci wysyłania wojska na operacje poza granice państwa. Oczywiście Autor zastrzega, że są to tylko prognozy, a szczególnie te dotyczące kierunków polskiej polityki i realizacji programów wyborczych są w realiach polskich bardzo ryzykowne. Tym niemniej zadaniem badacza jest nie tylko odpowiedź na pytanie jak jest i dlaczego tak jest, ale i próba odpowiedzi na pytanie jak będzie.

\section{Bibliografia}

Biala Księga Bezpieczeństwa Narodowego RP, Warszawa 2013.

Ciupiński A. (2014), Zdolności wojskowe Unii Europejskiej. Perspektywy grup bojowych, „Rocznik Integracji Europejskiej", nr 8.

Dobrowolska-Polak J. (2014), Stanowisko Polski wobec operacji wojskowych Unii Europejskiej w Afryce, w: Operacje wojskowe Unii Europejskiej w Afryce, pod red. B. Przybylskiej-Maszner, Poznań.

Doktryna Komorowskiego - zalożenia, 17.02.2014, www.bbn.gov.pl.

EUFOR RCA, European Union External Action, 13.07.2015, www.eeas.europa.eu.

EUTM Mali, European Union External Action, 13.07.2015, www.eeas.europa.eu.

Fryc M. (2014), „Doktryna Komorowskiego”- próba scharakteryzowania. Idea, zakres, priorytety, realizacja, „Bezpieczeństwo narodowe”, nr II.

Lasoń M. (2008), Udzial Polski w misjach pokojowych Unii Europejskiej na przykladzie misji w Demokratycznej Republice Konga i Republice Czadu, „Krakowskie Studia Międzynarodowe”. nr 4.

Monitor Polski, Dziennik Urzędowy Rzeczypospolitej Polskiej, Warszawa, dnia 15 grudnia 2014 r. poz. 1180, Postanowienie Prezydenta Rzeczypospolitej Polskiej z dnia 12 grudnia $2014 \mathrm{r}$. o przedlużeniu okresu uzycia Polskiego Kontyngentu Wojskowego w operacji wojskowej Unii Europejskiej w Republice Srodkowoafrykańskiej, www.bip.mon.gov.pl.

Monitor Polski, Dziennik Urzędowy Rzeczypospolitej Polskiej, Warszawa, dnia 14 kwietnia 2014 r. poz. 351, Postanowienie Prezydenta Rzeczypospolitej Polskiej z dnia 14 kwietnia 2014 r. 
o użyciu Polskiego Kontyngentu Wojskowego w wojskowej misji doradczej Unii Europejskiej w Republice Środkowoafrykańskiej, 14 IV 2015, www.bip.mon.gov.pl.

Monitor Polski, Dziennik Urzędowy Rzeczypospolitej Polskiej, Warszawa, dnia 13 lutego 2013 r. poz. 71, Postanowienie Prezydenta Rzeczypospolitej Polskiej z dnia 7 lutego 2013 r o użyciu Polskiego Kontyngentu Wojskowego w misji szkoleniowej Unii Europejskiej w Republice Mali, 13 II 2013, www.bip.mon.gov.pl.

Myślac Polska. Konwencja programowa Prawa i Sprawiedliwości oraz zjednoczonej prawicy, Katowice, 3-5 lipca $2015 \mathrm{r}$.

Ojrzanowski M. K. (2013), Strategiczne założenia NATO-implikacje dla Sit Zbrojnych RP, w: NATO wobec wyzwaí wspótczesnego świata, pod red. R. Czulda, R. Łoś, J. Regina-Zacharski. Warszawa-Lodź 2013.

Petny zapis przebiegu posiedzenia Komisji Obrony Narodowej (nr 99) z dnia 8 października 2014 r. Kancelaria Sejmu. Biuro analiz sejmowych, 8.10.2014, www.sejm.gov.pl.

PKW Mali, oficjalna strona internetowa o Polskim Kontyngencie Wojskowym w Mali, www.pkw.mali.wp.mil.pl.

Prezydent: Koniec polityki ekspedycyjnej, 15.07.2013, www.prezydent.pl.

Priorytety polskiej polityki zagranicznej 2012-2016, Warszawa 2012.

Radziejowska M., Terlikowski M. (2014), Operacja UE w Republice Srodkowoafrykańskiej a polskie zaangażowanie w misje ekspedycyjne, „Biuletyn PIMS”, nr 70(1182), 28 V 2014.

Rawski A. Z. (2011), Wojsko Polskie w misjach i operacjach Unii Europejskiej, Lublin.

Strategia bezpieczeństwa narodowego Rzeczypospolitej Polskiej, Warszawa 2014.

Strategia rozwoju systemu bezpieczeństwa narodowego Rzeczypospolitej Polskiej 2022, 9.04.2013 r., Warszawa 2013.

Strategia udzialu Sil Zbrojnych Rzeczypospolitej Polskiej w operacjach międzynarodowych, Warszawa, 13.01.2009.

Zapis stenograficzny. Posiedzenie Komisji Obrony Narodowej (87.) $w$ dniu 5 lutego 2015 r., 5.02.2015, www.senat.gov.pl.

Zdrowie, rodzina praca. Program Prawa i Sprawiedliwości 2014, Warszawa 2014.

Zięba R. (2012), Polska we Wspólnej Polityce Bezpieczeństwa i Obrony Unii Europejskiej, „Polityka i społeczeństwo", nr 10.

\section{Streszczenie}

Artykuł poświęcony został zaangażowaniu Polski w operacje wojskowe Unii Europejskiej w Afryce w drugiej dekadzie XXI wieku. Mimo, że rozwój zdolności wojskowych nie należy do priorytetów Unii Europejskiej, to organizacja ta włącza się aktywnie w podejmowane przez społeczność międzynarodową próby pomocy państwom afrykańskim także poprzez użycie sił zbrojnych. Zdecydowana większość tego typu misji unijnych realizowana była właśnie na kontynencie afrykańskim. Chociaż dla Polski nie jest to kierunek priorytetowy polityki zagranicznej i bezpieczeństwa, to ze względu na specyfikę współczesnych zagrożeń bezpieczeństwa oraz jej stosunek do procesu integracji europejskiej, włączyła się aktywnie w te działania. Jednak po pierwszych doświadczeniach z tym związanych i ograniczonej skuteczności realizacji stawianych przy tym celów narodowych związanych z rozwojem Wspólnej Polityki Bezpieczeństwa i Obrony UE, Polska ograniczyła swoje zaangażowanie. Ma to swoje odzwierciedlenie w dokumentach i linii politycznej związanej z wysyłaniem wojsk poza granice państwa. Autor stawia 
tezę, że ograniczenie to jest zbyt daleko idace $\mathrm{i}$ istnieją powody do zwiększenia polskiego wkładu w misje wojskowe Unii Europejskiej.

Slowa kluczowe: operacje wojskowe, Afryka, Unia Europejska, Wspólna Polityka Bezpieczeństwa i Obrony UE, Polska

\section{Poland's involvement in the European Union's military missions in Africa in the 2010s}

\section{Summary}

This paper is dedicated to the involvement of Poland in the European Union's military operations in Africa in the 2010s. The development of military capabilities is not one of the European Union's priorities. Nevertheless, the EU is an active participant of the international communities' efforts to aid African states, including the use of armed forces. The vast majority of such EU missions have been undertaken in Africa. Despite the fact that this region is not a priority of Poland's foreign and security policies, Poland has actively participated in such actions, primarily due to the peculiarities of contemporary security threats and Poland's approach to the process of European integration. However, after initial experiences, Poland limited its involvement, due to the limited impact on the achievement of national objectives related to the EU Common Security and Defence Policy. This has been reflected in both official documents and political practice associated with deploying troops on foreign soil. The author sets forth a thesis that these limitations are too substantial, and that there are reasons for greater Polish involvement in the European Union's military missions.

Key words: military operations, Africa, European Union, EU Common Security and Defence Policy, Poland 